\title{
Development of Mathematical Learning Devices Using Van Hiele Theory in Geometry of The Students In Grade VIII Secondary High School
}

\author{
$1^{\text {stEdwin Musdi }}$ \\ Mathematics Department \\ Universitas Negeri Padang \\ Padang, Indonesia \\ win_musdi@yahoo.co.id
}

\author{
$2^{\text {nd }}$ Nila Gsunita \\ Secondary High School \\ Padang, Indonesia
}

\begin{abstract}
This study was caused by lack of achievement mathematic students' in learning geometry. It can be understood from the observations and the results of daily tests of mathematics students in any of the material geometries in junior high school in Padang. More than $70 \%$ students have achievement geometry score less than the passing grade. The way to solve this problem was to develop a learning device by using the theory of Van Hiele. In this study, the learning device has been developed consist of lesson plan and worksheets based Van Hiele theory. The objective of this study was to product mathematics learning device that meet validity, practicality and effectiveness aspect to promote student learning outcomes in geometry. This type of research was the research development using a Plomp model which consists of three phases: a preliminary study, the prototype phase and the assessment phase. The subject of field test in this study were grade VIII students at SMPN 13 Padang in 2015/2016 academic year. Data validity analysis showed that constructivism-oriented math learning device resulting in extremely valid category. Data were analyzed using basic statistics. To find out the difference in geometry learning outcomes between the experimental and control classes used a t-test for a 5\% significance level. In data practicality analysis showed that learning device based on Van Hiele teory was practical because it can be applied well in math learning process. Moreover, the level of final result completeness increased up to $78,88 \%$. It means that this device is effective in improving students' achievement of learning geometry. This finding was in line previous study that although many studies all over the world demonstrated that Van Hiele theory can help improve geometric understanding. Based on this study, it recommended that teachers can implement van Hiele's theory in teaching geometry.
\end{abstract}

Keywords - Geometry Achievement, Van Hiele Theory.

\section{INTRODUCTION}

Geometry is a part of mathematics which aims to enable students to understand the nature and relationship between geometrical elements and can solve problems related to geometry. However, there are still many students who have difficulty in learning geometry and have many misconceptions and lack of knowledge of geometry [8]. One of the causes of the difficulty of students in understanding geometry is the learning strategy used is not in accordance with the material being taught. In addition, in the learning of geometry has not been adapted to the level of development of students' thinking. Therefore, appropriate strategy is needed based on the level of students' thinking development in geometry.

Geometry with formal evidence is felt to be very separate from practical life. Different teaching methods have been tried by teachers to make students clear with formal geometry.

High school geometry with formal proof is hard and separated from practical life of learner. Many teachers' indents' to not understand learning mathematics [11].

Stages - to understand the concept of mathematics one of them studied in geometry, because the concepts and applications are found in everyday life. Geometric material studies objects in the form of facts, concepts, and principles. By mastering these objects well, it is expected that the ability of students to understand understanding of geometry can increase.

Based on observations made in Junior High School it seems that very little understanding of students on geometry material, where they can not distinguish the form of a two-dimentional figure of a kind and the properties of a flat build. It is also supported from data of daily test result of students in SMP Padang indicate that mastery of mathematics material of student still low.

To improve the understanding of geometry, we developed the geometry learning based on Van Hiele theory. Van Hiele Theory guides teacher to 
create some instructions in order to make the class be more effective for learning [12]. Learning devices in this study includes lesson plan and student work sheets. Lesson plan and worksheets using van Hiele theory contain learning steps ranging from recognition, analysis, ordering, deduction and rigor. The five levels are described below (Khoh, 1998). The Van Hiele model emphasizes the importance of the teaching and learning process. Student progress from one level to the next as a result of the learning process is organized into five sequential stages of activities that emphasize exploration, discussion and integration (Tepo, 2013).

\section{Level 1 (Recognition)}

At level 1, Students recognize geometric figures according to their own appearance and see the overall shape. The characteristics of the figures do not play a role in the recognition of the figure. At this stage, a student will identify a square but will not be able to articulate that it has four congruent angles [2].

\section{Level 2 (Analysis)}

At level 2, the characteristic of the geometry figures become important for the student and become as a tool of identifying figures. The student sees properties separetely and do not connect the properties to each other. A student are capable to identify that a parallelogram has two pairs of parallel sides, and that if a quadrilateral has two pairs of parallel sides it is identified as a parallelogram [2]. At this stage students perceive relationships among properties and figures. They can make good definitions. They are able to give simple reasons to justify on their reasoning. They could draw logical maps and diagrams [5]; [12].

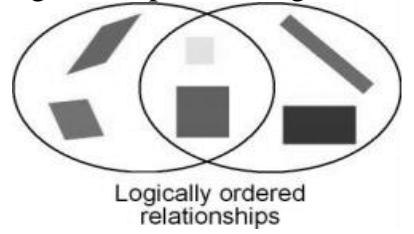

Figure 1. Children at Level 2 can draw a logical map of parallelograms.

Level 3 (Ordering)

The relationships between the various properties of the figure are now understood. It is only at this level that definitions make sense (although they may not be expressed in minimum terms). The students are not able to distinguish between necessary and sufficient conditions. The deduction method starts to appear but at elementary stage.

\section{Level 4 (Deduction)}

At level 4, student understands the importance of deduction and can understand the logical development of a proof. Definitions are using necessary and sufficient conditions are understood.

\section{Level 5 (Rigour)}

The essence of geometry and necessity for rigour is appreciated. Students can receive logically correct proofs even if the concepts are counter to intuition. At this stage, the student can comprehend nonEuclidean systems in terms of purely axiomatic structures.

In lesson plan, Van Hiele's activities are found in the core activities and on the worksheet. Mathematics learning using Van Hiele theory is a theory about the development of thinking in learning and to solve problems about geometry. The objective this research was to produce a mathematical learning device based on Van Hiele theory that meets the valid, practical and effective aspects to promote geometry acheivement of students.

\section{METHODS}

This research was a development research using the Plomp model (Plomp, 2013). There were three phases that was preliminary, prototyping, and assessment phase. The preliminary phase included the analysis of needs, curriculum, conceptual and student. In prototyping phase, we used formative evaluation (one to one, small group, and filed test evaluation). Prototyping phase consists of prototype 1 , that was self evaluation and expert review; prototype 2 is one to one evaluation; prototype 3 is small group teaching; prototype 4 is field test [1]. In the assessment phase was conducted in grade VIII.5 SMPN 13 Padang to see the practicality and effectiveness of devices. The research data is collected through self evaluation sheet, validation sheet, observation sheet and interview, teacher and student response questionnaire, observation sheet of lesson plan implementation, quiz and final test of learning result. The device validation was done by three lecturers of mathematics, one Indonesian lecturer, and one lecturer of Educational Technology. Data were analyzed using basic statistics to find out the difference in geometry learning outcomes between the experimental and control classes used a $\mathrm{t}$-test for a $5 \%$ significance level.

\section{RESULT AND DISCUSSION}

\section{Preliminary Research}

The purpose of this stage is to determine the requirements for the development of mathematical learning device. This stage is conducted by analyzing the objectives within the developed subject matter. There are four basic steps in this phase:

a. Need Analysis

Activity in needs analysis is the researchers gather information about the problems contained in existing learning and mathematics learning device. Information gathering is conducted with interviews with teachers, observing the implementation of learning and analyzing existing learning tools (lesson plan and worksheet). Interviews were conducted 
with several teachers in various schools related to lesson plan and worksheet. From interviews conducted with teachers, information is obtained that teachers have used worksheet during the learning process, but it has not led the participants to be actively involved in learning and has not directed learners to find their own concept of the material being studied. Worksheet used is commonly sold by school sellers and contains material, formulas given directly, examples of problems and practice.

Understanding concept of the mathematics student is still low. This is because learners in learning the geometry is given directly the content and its formulas by the teacher so they only memorize the formula and do not understand the formula background. For example to solve the problem of finding the rectangular pyramid surface area, the learner can not solve the problem because students only memorize the triangular pyramid formula, and do not understand deeply the formula of rectangular pyramid surface area.

At the stage of curriculum analysis conducted on the curriculum used in the school where the research conducted. The analysis of the curriculum includes competency standards and basic competencies that can be seen in the content standards and learning objectives. Curriculum analysis is done by analyzing competency standards and basic competence, materials, learning objectives, and indicators to be achieved. The curriculum analysis aims to make the mathematics learning tools produced in accordance with the competence demands that must be achieved by the learners.

\section{a. Concept Analysis}

Conceptual analysis is the identification of key concepts to be learned by the students and arranged them systematically according to the order of presentation. This analysis aims to determine the content and subject matter needed in the development of learning tools. Material is needed to achieve the indicators of achievement of competence. The material of class VIII SMP in the second semester developed in the scope of geometry and measurement.

b. Learner Analysis

Analysis of the learners is done to determine the characteristics of learners that include age, preferences of learners and needs in terms of learning media and learning resources desired. Based on the analysis of learners in terms of age, generally students who sit in grade VIII of Junior High School has an average age of 13-14 years According to Piaget's learning theory at the formal operational stage of 12-13 years the basic characteristics of its development are capable of thinking abstractly, logically, drawing conclusions, interpreting and developing hypotheses. Based on this Piaget theory, the students who become the object of the researcher have been able to think abstract, logical and draw conclusion, because in
Van Hiele theory there is a stage of drawing conclusion, so the students have been able to conclude what is learned later.

\section{Prototyping Phase}

a. Lesson Plan Design

Lesson Plan is a plan of face-to-face learning method that used for one or more meetings. Learning activities consist of three phases that are opening, core activity and closing. In the preliminary activities, there are activities to open learning, apperception and motivation. In the core activities there are activities in accordance with the phases of Van hiele theory. At closing activities there are activities of concluding the lesson and directing it to the following meeting.

The worksheet is designed to direct student activities to follow the phases of van Hiele's theory. Before being used, the worksheet is validated by four validators. During validation there are some suggestions provided by the validator to be fixed. After it was corrected, it was given again to the validator to be validated again. Average index practice by four calidators is 3.56 are on the criterion is very valid.

b. One to one evaluation

The purpose of a one-to-one evaluation is to identify the possible errors in the worksheet such as the language, the less obvious worksheet instructions, and the ease of using the worksheet. One-to-one evaluation is done by asking learners to read, understand and do the activities contained in worksheet. From the one-to-one evaluation, the average value of worksheet practicality was $77.78 \%$. It was in the practical criteria.

\section{c. Small Group Evaluation}

Small group evaluation is carried out by implementing real teaching with limited learner. Small group evaluation was done on eight students with different ability that is low, medium and high learners grade VIII. Based on a questionnaire of practicality that has been filled by the learner on a small group evaluation, the average worksheet practice average is $85 \%$. It indicating that the worksheet is already in very practical criteria.

\section{d. Field Test}

After a small group evaluation was carried out, improvements were made to perfect of the learning device, the lesson plan and the worksheet. After the repair was done, then the device was used in the actual class. Field test was conducted at SMPN 13 Padang with subject of grade VIII.5.

Field tests conducted by teachers who teach mathematics grade VIII.5 that is Surinta Armela, S.Pd. After the learning device is completed in the field test, it was followed by an assessment of the learning device that has been made. Assessments was conducted to assess the learning device. 


\section{Assessment Phase}

Assessment phase is done after the field test is done to the students of grade VIII.5 SMPN 13 Padang. Assessment was done to see the practicality and effectivity of learning device.

a. Practicality of Learning Devices

Practicality of mathematics learning device was done to see the practicality level of instructional device used in learning process. Based on questionnaires from teachers after the lesson learned on field test activities, the learning value of learning tool practicality is $85.25 \%$ are on very practical criteria.

b. Effectiveness of learning devices

The effectiveness of the use of mathematics learning devices using Van Hiele theory that has been developed is seen by giving the test to know the student learning outcomes. From the results of tests that have been given, obtained the average value of learning outcomes of learners is 78.88. the figure ware more than the passing grade.

\section{CONCLUSION}

Based on current study, we concluded the following conclusions:

1. The results showed that the mathematics learning device based on Van Hiele theory was in valid category both in terms of content and constructs.

2. The results showed that the mathematics learning device based on Van Hiele theory already meet the practical criteria. This can be seen from the data of teacher and students responses, and from interviews with teachers and students.

3 . The results showed that the mathematics learning device using Van Hiele theory has been effective in improving student learning outcomes. This is seen from the completeness of student learning outcomes $82.35 \%$ to reach minimal passing grade.

Based on the findings of this research, learning by applying Van Viele theory increase students' geometric understanding. This is because students learn geometry through the step by step of the theory. This finding was in line with the results of research conducted by Vojkuvkova [12] and Crowley [5] that is although many studies all over the world demonstrated that Van Hiele theory can help improve geometric understanding. The results of this study indicate that students' activities in learning geometry increase in accordance with the results obtained by Choi-Koh, Sang Sook [4].

In addition, by comparison with the traditional class, there is a significant difference between the classes taught by Van Hiele theory with the traditional class for a significance level of 5\%. The results of this research were in line with the findings by [6]. From the opinion of teachers who teach using the Van Hiele theory, the learning is more structured and allows students to understand the geometry easily. The results of this study recommended that teachers can use Van Hiele's theory in classroom mathematics teaching.

\section{REFERENCES}

[1] Akker, J.V, "Principles and Methods of Development Research. In J. Vam den Akker,R Branch,K Gustafson, N Nieveen and Tj.Plomp (Eds). Design Approaches and Tools in Education and Training", Dodrecht : Kluwer Academic Publisher, pp. 1-14, 1999.

[2] Breyfogle and Lynch, Van Hiele Revisited, "Mathematics Teaching in the Middle School", Vol. 16, 2010.

[3] Crowley, Mary L. "The van Hiele Model of the Development of Geomemc Thought." In Learning and Teaching Gemretry, K-12, 1987 Yearbook of the National Council of Teachers of Mathematics, edited by Mary Montgomery Lindquist, pp.1-16. Reston, Va.: National Council af Teachers af Mathematics, 1987 https://doi.org/10.1016/j.sbspro.2012.09.557

[4] Choi-Koh, Sang Sook, "The Activities Based on van Hiele Model Using Computer as a Tool", Journal of the Korea Society of Mathematical Education Series D: Research in Mathematical Education vol. 4, pp. 63-77, 2000.

[5] Crowley, Mary L, "The van Hiele Model of the Development of Geomemc Thought. In Learning and Teaching Geometry, K-12, 1987 Yearbook of the National Council of Teachers of Mathematics", edited by Mary Montgomery Lindquist, Reston, Va.: National Council af Teachers af Mathematics, pp.1-16, 1987.

[6] Gutierrez and Jaime, "On the Assessment of the Van Hiele Levels of Reasoning", Focus on Learning Problems in Mathematics Sprimg \& Summer Edition 1998, Vol. 20 (c) Center for Teaching/Learning of Mathematics, 1998.

[7] Khoh, Lim Suat, "Applying the Van Hiele theory to the Teaching of Secondary School Geometry, Teaching and Learning", vol.13, pp. 32-40, Institute of Education (Singapore), 1992.

[8] Ozerem, Aysen, "Misconceptions In Geometry And Suggested Solutions For Seventh Grade Students", International Conference On New Horizons In Education Inte2012, Procedia - Social and Behavioral Sciences 55 ( 2012 ) pp. $720-729,2012$.

[9] Plomp, T., \& Nieveen, N. (Eds.), "Educational design research: An Introduction. Enschede" ,the Netherlands: SLO. (free access at (www.international.slo.nl), 2013.

[10] Tepo, Anne, "Van Hiele Level of Geometry thought Revisited", National Council of Teachers of Mathematics is collaborating with JSTOR to digitize, preserve and extend access to The Mathematics Teacher, 2013.

[11] Van Hiele., P. M., "Developing Geometric Thinking through Activities that Begin with Play", Teaching Children Mathematics, vol. 5, pp. 310-316, 1999.

[12] Vojkuvkova, "The van Hiele Model of Geometric Thinking", WDS'12 Proceedings of Contributed Papers, Part I, pp. 72-75, 2012 